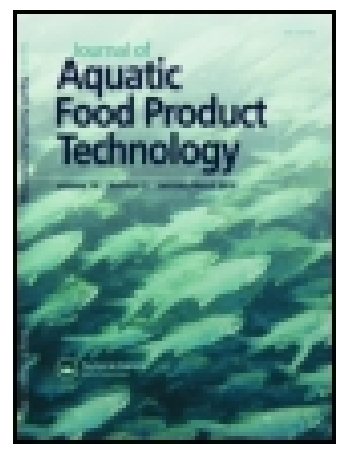

Journal of Aquatic Food Product Technology

\title{
Nutritional Evaluation of Indian Ocean Swimming Crab, Charybdis smithii (Portunidae), an Unconventional Crab Resource from the Indian Coast
}

K. Yogesh Kumar, A. P. Dineshbabu \& Sujitha Thomas

To cite this article: K. Yogesh Kumar, A. P. Dineshbabu \& Sujitha Thomas (2019): Nutritional Evaluation of Indian Ocean Swimming Crab, Charybdis smithii (Portunidae), an Unconventional Crab Resource from the Indian Coast, Journal of Aquatic Food Product Technology

To link to this article: https://doi.org/10.1080/10498850.2019.1567638

曲 Published online: 22 Jan 2019.

Submit your article to this journal $\pi$

View Crossmark data $₫$ 


\title{
Nutritional Evaluation of Indian Ocean Swimming Crab, Charybdis smithii (Portunidae), an Unconventional Crab Resource from the Indian Coast
}

\author{
K. Yogesh Kumar (D, A. P. Dineshbabu (D), and Sujitha Thomas (1) \\ Research Centre Mangalore, ICAR - Central Marine Fisheries Research Institute, Mangalore, India
}

\begin{abstract}
Investigations were carried out to determine the nutritional profile of Indian Ocean swimming crab Charybdis smithii, which is emerging as an unconventional resource in trawl discards of India. The average protein content was $9.38 \mathrm{~g} / 100 \mathrm{~g}$, fat $0.86 \mathrm{~g} / 100 \mathrm{~g}$, ash $0.34 \mathrm{~g} / 100 \mathrm{~g}$, fiber $0.13 \mathrm{~g} / 100 \mathrm{~g}$, and carbohydrate $1.8 \mathrm{~g} / 100 \mathrm{~g}$. One-way analysis of variance showed no significant variations of constituents except in dry matter and carbohydrate between sexes. Macronutrients, $\mathrm{Na}(317.1,327.6 / 100 \mathrm{~g}), \mathrm{K}(148,177.40 \mathrm{mg} / 100 \mathrm{~g}), \mathrm{Ca}$ (187.90, $285.80 \mathrm{mg} / 100 \mathrm{~g})$, and $\mathrm{Mg}(34.31,41.49 \mathrm{mg} / 100 \mathrm{~g})$, showed significant variation between sexes. The composition of micronutrients in male and female were $\mathrm{Cu}(0.28,0.15 \mathrm{mg} / 100 \mathrm{~g})$, Fe $(0.57,0.71 \mathrm{mg} / 100 \mathrm{~g})$, and $\mathrm{Zn}(1.71$, $2.75 \mathrm{mg} / 100 \mathrm{~g})$. Mineral content showed significant difference between sexes. Amino acid analysis showed that 12.04 and $11.47 \mathrm{~g} / 100 \mathrm{~g}$ essential amino acid glycine was present in male and female, respectively, and lysine concentration was 13.96 and $12.65 \mathrm{~g} / 100 \mathrm{~g}$, respectively. The nutritional profile of the species was determined the first time and shows that it is comparable with any other edible crabs and could be exploited as a commercial resource to supplement nutritional demand.
\end{abstract}

\section{KEYWORDS}

Unconventional; Charybdis smithii; proximate composition; mineral composition; amino acid; fatty acid

\section{Introduction}

Demand for seafood is increasing worldwide due to increasing health consciousness. Apart from its widely accepted taste, crustaceans, especially shrimp, lobster and crab, are recognized as a good source of protein and mineral supplement to human health (Chigozie and Kolade, 2015). The marine fishery has shown signs of depletion during the last two decades, and the quantity of conventional commercial fishery resources have depleted rapidly (Worm et al., 2006). Since seafood is recognized as a healthy food in terms of protein, unsaturated fatty acids, and minerals, the demand for seafood in the global market is increasing. However, a huge quantity of the marine fish catch is being discarded (Alverson et al., 1994; Kelleher, 2005) due to lack of market demand. Among crustaceans, marine crabs are the most diverse group and have great demand as food. In India, conventional edible varieties of crabs contributing to the fishery economy are dominated by the spotted crab Portunus sanguinolentus and the blue swimmer crab Portunus pelagicus. Charybdis lucifera, Charybdis annulata, and Charybdis natator have also been identified as edible varieties in different coastal areas of the country (Radhakrishnan et al., 2007). The cross crab, Charybdis feriatus, which is caught as bycatch in trawling, is a preferred seafood. As the demand has increased, the landing of the species has also increased with extension of trawl fishing area (Dineshbabu, 2011). When trawling extended beyond $100 \mathrm{~m}$ depth, the Indian Ocean swimming crab, Charybdis smithii, emerged as a significant component of the trawl catch. Through exploratory surveys, Silas (1969)

CONTACT K. Yogesh Kumar yogeshkk58@gmail.com @ Research Centre Mangalore, ICAR- Central Marine Fisheries Research Institute, P.B. No. 244, Mangalore 575001, India.

(C) 2019 Taylor \& Francis Group, LLC 
and Sulochanan et al. (1991) predicted that C. smithii has the potential of forming a commercial fishery; and Balasubramanian and Suseelan (2001a) have identified its wide distribution within the Indian Exclusive Economic Zone (EEZ). The biomass estimation showed that in the Indian EEZ, the biomass of the species was as high as $1,740 \mathrm{~kg}$ per ha (Balasubramanian and Suseelan, 2001a). Romanov et al. (2009) reported that these crabs aggregate at night in the upper 150-m layer, and the estimated biomass derived from pelagic trawling exceeded $130 \mathrm{~kg} / \mathrm{km}^{2}$. They also reported that abundance of $C$. smithii can reach 15,000 individuals $/ \mathrm{km}^{2}$ during the southwest monsoon along the equatorial Indian Ocean. A recent study from the southwest coast of India showed that a huge quantity of C. smithii are found in trawl discards. During 2008-2009, out of estimated discards from trawlers operated off 100-m depth from Mangalore fisheries harbor, C. smithii formed about $2.9 \%$ of the discards (Dineshbabu et al., 2012).

The nutritive value and biochemical composition of crab meat have been studied in various parts of the world, including edible and non-edible species from Indian Ocean waters (Jeyalakshmi and Chandran, 2014; Kathirvel et al., 2014; Premarathna et al., 2015; Soundarapandian et al., 2013). Preliminary investigations carried out on biochemical composition revealed that there is a potential for the species to be recognized as a safe human food (Balasubramanian and Suseelan, 2001b). The present work determined the proximate nutrition components of the species, in order to supplement the information on the nutritional quality of the species as human food. Recognition of C. smithii as a healthy seafood will increase the demand for the species in the seafood market, resulting in additional income for the fishermen and also reduction of resource loss by avoiding/reducing discard of the species. Detailed biochemical composition of C. smithii was determined for the first time, and no previous reports are available on this species.

\section{Materials and methods}

For the study, samples of Charybdis smithii were collected from the landings of multiday operating trawlers from Mangalore fishing harbour during January 2015 to December 2016. A part of C. smithii catch was packed in ice immediately after bringing it to the deck. The samples collected from the boat were brought to the laboratory. After sex-wise segregation, the carapace of individual crab was removed, and the crab meat, including the meat from chelate legs, was extracted and transferred to a Petri dish for further analysis. Carapace width (CW), carapace length, and the body weight were determined.

\section{Proximate and mineral analysis}

Triplicate samples of 30 males and 30 non-berried females were analyzed for moisture content. Known weight of the sample was kept at $80^{\circ} \mathrm{C}$ in hot air oven overnight to attain constant weight to ensure that the moisture content of the sample was completely evaporated (Vijayagopal et al., 2015). Dry matter $(\mathrm{DM})$ of the sample was determined by drying at $105^{\circ} \mathrm{C}$ for $24 \mathrm{~h}$ in a hot air laboratory oven with a fan with forced air circulating system (Vijayagopal et al., 2015). Crude protein $(\mathrm{CP})(\mathrm{N} \times 6.25)$ of the crab meat was estimated by micro-Kjeldahl method (Humphries, 1956), crude lipid (CL) was estimated using petroleum ether $\left(60-80^{\circ} \mathrm{C}\right.$ boiling point) by Soxhlet apparatus. Crude fiber (CF) was determined by the remaining fraction after refluxing with a standard solution of $\mathrm{H}_{2} \mathrm{SO}_{4}$ and $\mathrm{NaOH}$ under controlled conditions for $30 \mathrm{~min}$ (AOAC, 1995). The nitrogen-free extract (NFE) of diets considered as total carbohydrates was derived by subtracting CP, CL, CF, and ash from DM (Vijayagopal et al., 2015).

\section{Minerals}

Mineral estimation was carried out by the method of inductively coupled plasma-optical emission spectrometric (ICP-OES) determination of elements using microwave-assisted digestion. Ten microliters of nitric acid was used for digestion for $10 \mathrm{~min}$. After digestion, the samples were made up to 
$100 \mathrm{ml}$ and introduced to ICP-OES machine ICAP 6300 for analysis (Horwitz and W Latimer, 2005; Latimer, 2012).

\section{Amino acid analysis}

The amino acid content of crab meat was determined based on the study of Hofmann et al. (1997, 2003) using isotope with gas chromatography-combustion-isotope ratio mass spectrometry (GCC-IRMS/MS) (GC: Hewlett-Packard 58590 series II, Germany; combustion series II-interface, IRMS MAT 252, Finnigan MAT, Germany; MS: GCQ, Finnigan MAT, Germany). The capillary column of dimension $50 \mathrm{~m} \times 0.32 \mathrm{~mm}$ i.d. $\times 0.5 \mu \mathrm{m}$ BPX5 (SGE) was connected to gas chromatography. The flow of carrier gas (helium) was maintained at $1.5 \mathrm{ml} / \mathrm{min}$, with the head pressure $13 \mathrm{psi}$. A weighed amount of crab meat sample was treated with hydrochloric acid $\left(6 \mathrm{~N}, 15 \mathrm{ml}, 145^{\circ} \mathrm{C}, 4 \mathrm{~h}\right)$, and oxidized samples were used for sulphur amino acid. For tryptophan analysis, alkaline hydrolysis was followed instead of acid hydrolysis, since it is stable at basic condition. The solutions were evaporated to dryness using a rotary evaporator (Büchi Laboratoriumstechnik AGRE121; Switzerland) connected to a diaphragm vacuum pump (MC2C; Vacuubrand GmbH, Germany) to remove hydrochloric acid. For the process of derivatization, trans-4-(aminomethyl)cyclohexanecarboxylic acid (purity, 97\%; Sigma Aldrich, St. Louis, MO, USA) was added to hydrolysate as internal standard. The standards were treated with dichloromethane and dried to remove moisture by flushing inert helium with passive heating in an oil bath $\left(60^{\circ} \mathrm{C}\right)$. The acidified isopropanol $(12 \mathrm{ml})$ (acetyl chloride +2 -propanol) $(1: 4 \mathrm{v} / \mathrm{v})$ was added following heating $\left(100^{\circ} \mathrm{C}\right.$, $1 \mathrm{~h})$. The contents were evaporated to dryness in the oil bath at $60^{\circ} \mathrm{C}$ by gently flushing helium. The dry residue was evaporated and treated with dichloromethane; this process was repeated to remove traces of isopropanol and water. The final residues were treated with trifluroacetic anhydride of $200 \mathrm{ml}$ volume overnight at room temperature. Then, the fraction of the solution was injected in GC-C-IRMS/MS. The details of temperature program are given in Table 1. Classification of Nelson and Cox (2004) was adopted for classification of amino acids as nutritionally "essential" or "nonessential" or "conditionally essential."

\section{Fatty acid analysis}

Hot extracted crude fat from crab meat was used for determining the fatty acid methyl esters (FAMEs). The method suggested by Padua-Resurreccion and Banzon (1979) was used for this process. The analytical techniques such as FAMEs were quantified by gas chromatographer (GC2010, Shimadzu, Japan) equipped with fused silica column (BPX-70) and flame ionization detector (FID). Methylation was performed by the acid-catalyzed method. The trans-esterified samples $(100 \mu \mathrm{l})$ were made up to $1 \mathrm{ml}$ by $n$-hexane, and the fraction of samples $(1 \mu \mathrm{l})$ was injected into a gas chromatograph for analysis. The identification of peaks obtained from the lipid profiling was determined by comparing with National Institute of Standards and Technology Library (NIST 11 mass spectrometry library; NIST/EPA/NIH; version \# 2011). Further analysis was carried out following the methodology suggested by Nareshkumar (2007).

Table 1. Temperature program for GC-C-IRMS/MS.

\begin{tabular}{lcc}
\hline Time $(\mathrm{min})$ & Temperature $\left({ }^{\circ} \mathrm{C}\right)$ & Temperature/min \\
\hline 1 & 50 & Start \\
10 & $50-100$ & $10^{\circ} \mathrm{C} / \mathrm{min}$ \\
10 & $100-175$ & $3^{\circ} \mathrm{C} / \mathrm{min}$ \\
10 & $175-200$ & $3^{\circ} \mathrm{C} / \mathrm{min}$ \\
10 & 250 & Stop \\
\hline
\end{tabular}




\section{Statistical analysis}

Experimental species were subjected to one-way analysis of variance (ANOVA). Independent variables were used to determine the significance level between male and female for the proximate composition, mineral composition, fatty acid, and amino acid analysis using the Statistical Package for Social Sciences, 16.0 software (SPSS Inc., 2007, Chicago, IL, USA).

\section{Results}

\section{Description of the species}

Charybdis (Goniohellenus) smithii MacLeay, 1838 is a decapod crab belonging to family Portunidae. For the present study, the samples were collected from trawlers operating off Malabar and Konkan coast of Eastern Arabian Sea, at a depth of 100-150 m. Males collected were in the size range of 36-68 $\mathrm{mm} \mathrm{CW}$, with a weight range of 4-64 $\mathrm{g}$ (mean size $55 \mathrm{~mm}$ and mean weight $27 \mathrm{~g}$ ). In females, the size range and weight were 35-62 mm CW and 4-45 g (mean size of $49 \mathrm{~mm} \mathrm{CW}$ and mean weight of $21 \mathrm{~g}$ ), respectively.

\section{Proximate composition}

The results of the proximate composition of the males and females $C$. smithii expressed in wet weight are given in Table 2. The dry weight of males and females was $13.02 \pm 0.09 \mathrm{~g} / 100 \mathrm{~g}$ and $12.07 \pm 0.02 \mathrm{~g} / 100 \mathrm{~g}$, respectively, showing more moisture content in females compared to males, whereas the protein and fat content of the males was more than in females. The protein value in males and females was $9.48 \pm 0.29 \mathrm{~g} / 100 \mathrm{~g}$ and $9.27 \pm 0.29 \mathrm{~g} / 100 \mathrm{~g}$, respectively, and fat content was $0.92 \pm 0.02 \mathrm{~g} / 100 \mathrm{~g}$ in males and $0.79 \pm 0.17 \mathrm{~g} / 100 \mathrm{~g}$ in females. Similarly, ash content and carbohydrate were higher in males, but fiber content was higher in females. The variation in composition between males and females was not statistically significant $(p<0.001)$, except in DM and carbohydrate.

The mineral composition of copper $(\mathrm{Cu})$, zinc $(\mathrm{Zn})$, manganese $(\mathrm{Mn})$, iron $(\mathrm{Fe})$, magnesium $(\mathrm{Mg})$, sodium $(\mathrm{Na})$, potassium $(\mathrm{K})$, and calcium $(\mathrm{Ca})$ were analyzed during the study, and the results are shown in Table 3 . The study showed that both male and female crabs are rich in $\mathrm{Na}, \mathrm{K}, \mathrm{Ca}$, and $\mathrm{Mg}$, and female crabs contained higher amount of minerals than males (Table 3). Minerals in males and females showed highly significant variation $(p<0.001)$ for sodium, potassium, and calcium, whereas for zinc, the variation was significant at $5 \%$ level $(p<0.05)$.

After ascertaining the richness in protein content, the samples were further analyzed for amino acid composition. The results of the study are given in Table 4 and expressed in $\mathrm{g} / 100 \mathrm{~g}$ protein. Non-essential amino acids, such as alanine, asparate, glutamate, and serine, were analyzed in both sexes. It was found that the crab meat was rich in non-essential amino acids, and meat of male crabs was comparatively richer in these components (Table 4). In the case of essential amino acid, such as histidine, isoleucine, leucine, lysine, methionine, phenylalanine,

Table 2. Proximate composition of crab C. smithii in $\mathrm{g} / 100 \mathrm{~g}$ wet weight.

\begin{tabular}{lcr}
\hline Proximate composition & Male & \multicolumn{1}{c}{ Female } \\
\hline Dry matter & $13.02 \pm 0.09$ & $12.07 \pm 0.02$ \\
Moisture & $86.98 \pm 0.21$ & $87.93 \pm 0.19$ \\
Protein & $9.48 \pm 0.29$ & $9.27 \pm 0.29$ \\
Fat & $0.92 \pm 0.02$ & $0.79 \pm 0.17$ \\
Fiber & $0.11 \pm 0.03$ & $0.14 \pm 0.02$ \\
Carbohydrate & $2.1 \pm 0.00$ & $1.53 \pm 0.01$ \\
Ash & $0.37 \pm 0.04$ & $0.30 \pm 0.03$ \\
\hline
\end{tabular}


Table 3. Mineral composition of crab C. smithii in $\mathrm{mg} / 100 \mathrm{~g}$ wet weight.

\begin{tabular}{lcr}
\hline Mineral composition & Male & Female \\
\hline Copper & $0.28 \pm 0.01$ & $0.15 \pm 0.02$ \\
Zinc & $1.714 \pm 0.56$ & $2.75 \pm 0.22$ \\
Manganese & $0 \pm 0$ & $0.02 \pm 0$ \\
Iron & $0.574 \pm 0.21$ & $0.71 \pm 0.01$ \\
Magnesium & $34.31 \pm 1.2$ & $41.49 \pm 0.29$ \\
Sodium & $317.1 \pm 0.86$ & $327.6 \pm 0.37$ \\
Potassium & $148 \pm 0.72$ & $177.4 \pm 0.49$ \\
Calcium & $187.9 \pm 0.55$ & $285.8 \pm 0.37$ \\
\hline
\end{tabular}

Values are given as mean \pm SD from triplicate determinations.

Table 4. Amino acid profile of crab C. smithii in $\mathrm{g} / 100 \mathrm{~g}$ protein.

\begin{tabular}{|c|c|c|}
\hline Amino acid profile in $\mathrm{g} / 100 \mathrm{~g}$ & Male & Female \\
\hline \multicolumn{3}{|l|}{ Non-essential amino acids } \\
\hline Asp & $4.06 \pm 0.42$ & $3.92 \pm 0.36$ \\
\hline Ser & $2.84 \pm 0.03$ & $2.95 \pm 0.25$ \\
\hline Glu & $9.73 \pm 0.55$ & $8.80 \pm 0.25$ \\
\hline Ala & $8.02 \pm 0.37$ & $8.56 \pm 0.84$ \\
\hline Total NEAA & 24.65 & 24.23 \\
\hline \multicolumn{3}{|c|}{ Conditionally essential amino acids } \\
\hline Arg & $8.46 \pm 0.21$ & $5.28 \pm 2.59$ \\
\hline Cys & $0.25 \pm 0.03$ & $0.15 \pm 0.07$ \\
\hline Gly & $12.03 \pm 1.42$ & $11.47 \pm 0.12$ \\
\hline Pro & $5.81 \pm 0.59$ & $6.63 \pm 0.59$ \\
\hline Tyr & $3.12 \pm 0.25$ & $3.3 \pm 0.11$ \\
\hline Total CEAA & 29.67 & 26.83 \\
\hline \multicolumn{3}{|l|}{ Essential amino acids } \\
\hline $\mathrm{His}$ & $1.82 \pm 0.23$ & $2.32 \pm 0.47$ \\
\hline Ile & $5.36 \pm 0.13$ & $5.52 \pm 0.49$ \\
\hline Leu & $8.17 \pm 0.30$ & $8.15 \pm 0.96$ \\
\hline Lys & $13.95 \pm 0.29$ & $12.65 \pm 0.57$ \\
\hline Met & $2.66 \pm 0.19$ & $2.97 \pm 0.02$ \\
\hline Phe & $3.83 \pm 0.03$ & $3.99 \pm 0.36$ \\
\hline Thr & $3.59 \pm 0.02$ & $4.53 \pm 1.05$ \\
\hline Val & $5.71 \pm 0.26$ & $6.14 \pm 0.41$ \\
\hline Trp & ND & ND \\
\hline Total EAA & 45.09 & 46.27 \\
\hline
\end{tabular}

Classification of AAs as nutritionally "essential" or "nonessential" or "conditionally essential" is as per Nelson and Cox (2004). Values are reported as mean \pm SD of three replicates; ND: not detected.

threonine, valine, and tryptophan, amounts were higher in females (Table 4.) The variation of amino acids glutamate, lysine, and methionine between the sexes showed statistical significance at 5\% level $(p<0.05)$; for the other amino acids, the variation noted between the sexes was not statistically significant.

The present study showed that $C$ smithii possess high fat content (males, $0.92 \pm 0.02 \mathrm{~g} / 100 \mathrm{~g}$ and females, $0.79 \pm 0.17 \mathrm{~g} / 100 \mathrm{~g}$ ). Fatty acid profile of the species was performed in order to understand the composition of these fats; results are given in Table 5. Among the saturated fatty acids (SFA), palmitic acid (C16), stearic acid (C18), palmitoleic acid (C16:1 Cis), and margaric acid (C17) were the dominant ones detected from the crab meat. Out of these, palmitic acid was the most dominant SFA, constituting 53.2\% of the total SFA. High levels of docosahexaenoic acid (DHA) (9.18 g/100 g) and eicosapentaenoic acid (EPA) (10.35 g/100 g) were also found in the crabs (Table 5). The ratio of EPA/DHA was found to be 1.12 (Table 6). For polyunsaturated fatty acids (PUFA), linoleic acid $3.67 \mathrm{~g} / 100 \mathrm{~g}$ was the dominant constituent, followed by EPA at $10.35 \mathrm{~g} /$ $100 \mathrm{~g}$ and DHA at $9.18 \mathrm{~g} / 100 \mathrm{~g}$ (Table 5). 
Table 5. Fatty acid profile of crab C. smithii in g/100 g lipid.

\begin{tabular}{|c|c|c|}
\hline & Fatty acid profile & $\mathrm{g} / 100 \mathrm{~g}$ \\
\hline \multicolumn{3}{|c|}{ Saturated fatty acid } \\
\hline C16:0 & Palmitic acid & $27.33 \pm 0.08$ \\
\hline $\mathrm{C} 16: 1 \mathrm{Cis}$ & Palmitoleic acid & $4.11 \pm 0.01$ \\
\hline $\mathrm{C} 17: 0$ & Margaric acid & $3.89 \pm 0.01$ \\
\hline C18:0 & Stearic acid & $15.98 \pm 0.05$ \\
\hline \multicolumn{3}{|c|}{ Monounsaturated fatty acid } \\
\hline C18: 1 Cis & Oleic acid & $25.46 \pm 0.07$ \\
\hline \multicolumn{3}{|c|}{ Polyunsaturated fatty acid } \\
\hline C18: 2 Cis & Linoleic acid & $3.67 \pm 0.01$ \\
\hline C20: 5 Cis & Eicosapentaenoic acid (EPA) & $10.35 \pm 0.07$ \\
\hline $\mathrm{C} 22: 6$ & Docosahexaenoic acid (DHA) & $9.18 \pm 0.02$ \\
\hline
\end{tabular}

Table 6. Sum of various classes of fatty acids and their ratio.

\begin{tabular}{lr}
\hline Fatty acid & $\%$ \\
\hline Total & 100 \\
SFA & 51.31 \\
MUFA & 25.46 \\
PUFA & 23.2 \\
PUFA/SFA & 0.45 \\
EPA/DHA & 1.12 \\
\hline
\end{tabular}

\section{Discussion}

The only reported work on the biochemical composition of the species gave a moisture content of $86-90 \%$, which is comparable to the present result (Balasubramanian and Suseelan, 2001a). While calculating wet weight, protein and CL content are estimated as 9.27-9.48 g/100 g and $0.79 \mathrm{~g} / 100 \mathrm{~g}$ to $0.92 \mathrm{~g} / 100 \mathrm{~g}$, respectively (which is equivalent to $73.07-76.99 \mathrm{~g} / 100 \mathrm{~g}$ protein and $6.60-7.13 \mathrm{~g} / 100 \mathrm{~g}$ fat in dry weight). The results of the present study are slightly higher than those reported by Balasubramanian and Suseelan (2001b) with dry weight calculation (59.8-71.1\% protein and $6.2-8.2 \%$ fat). This is comparable with shrimp Penaeus monodon, using wet weight for comparison (Premarathna et al., 2018). Carbohydrate composition in the present study $(2.1 \mathrm{~g} / 100 \mathrm{~g}$ and $1.53 \mathrm{~g} / 100 \mathrm{~g})$ is similar to results reported in earlier studies (0.4 and $0.3 \mathrm{~g} / 100 \mathrm{~g}$ of wet weight) (Musaiger and Al-Rumaidh, 2005). Comparing the studies on protein and carbohydrate content of other tropical portunid crabs (Badawi, 1971; Radhakrishnan and Natarajan, 1979; Thomas, 1985; Oramadike and Oluwakemi, 2015), C. smithii was found to have more or less similar concentrations. Richness in $\mathrm{Na}, \mathrm{K}, \mathrm{Ca}$, and $\mathrm{Mg}$ is identified as one of the major qualities of edible seafood (Chakraborty et al., 2016; Soundarapandian et al., 2014) and these constituents were found in considerably good quantity in the meat of C. smithii. Mineral content was comparable to that found by Musaiger and AlRumaidh (2005). EPA and DHA concentration in the Malaysian edible crab, Liocarcinus vernalis, was estimated to be 5 and 7\%, respectively (Rosli Wan et al., 2012), whereas C. smithii showed 9 and 10\%, respectively. The rich composition of amino acids and unsaturated fatty acids (omega- 3 and omega- 6 fatty acids) are considered as major criteria to qualify for a recommendation as healthy food (Dey Snigdha et al., 2017; Kris-Etherton et al., 2002; Swanson et al., 2012). The present study found crab meat of C. smithii to have a wide amino acid profile and higher levels of linoleic acid (3.67 g/100 g), DHA (9.18 g/100 g), and EPA $(10.35 \mathrm{~g} / 100 \mathrm{~g})$. High omega-6 concentration is reported to have physiological importance; because it accumulates in adipose tissues of the body (Jandacek, 2017), it can be projected as a favorable factor for recommending C. smithii meat as a healthy food. 


\section{Conclusion}

Based on the nutritive value of the species derived from this study, the popularization of C. smithii as human food can be pursued with awareness programs, and methods can be found to extract the various nutritive components from the crab meat to be used as food additives. In regard to fishery economics, increase in market demand of these crabs will result in the landing of the crabs in fresh and preserved form, thereby increasing the income of the fishermen as well as effectively reducing resource loss due to discarding.

\section{Acknowledgments}

The authors are thankful to Dr. A Gopalakrishnan, Director, Central Marine Fisheries Research Institute (CMFRI), Kochi and Dr. Prathibha Rohit, Scientist-In-charge CMFRI, Mangalore for the facilities provided for the work. Authors are also thankful to Dr. Ravishankar, C.N., Director, Central Institute of Fisheries Technology, Kochi for helping with the facilities to carry out some part of the study. The help rendered by the owner and crew members of "Harikripa" group of trawlers in collecting the samples in fresh form is also thankfully acknowledged. First author like to place on record, the gratitude to Ministry of Earth Sciences, Government of India for providing the fellowship for completing the research work.

\section{Disclosure statement}

No potential conflict of interest was reported by the authors.

\section{Funding}

This work was supported by the Ministry of Earth Sciences, New Delhi India.

\section{ORCID}

K. Yogesh Kumar (D) http://orcid.org/0000-0001-9112-8242

A. P. Dineshbabu (D) http://orcid.org/0000-0001-5056-4187

Sujitha Thomas (D) http://orcid.org/0000-0002-1696-1741

\section{References}

Alverson, D. L., Freeberg, M. H., Murawski, S. A., and Pope, J. G. 1994. A global assessment of fisheries bycatch and discards. FAO Fisheries Tech. Paper. No. 339. Rome, FAO. 233. doi: 10.3168/jds.S0022-0302(94)77044-2

AOAC. 1995. Official Methods of Analysis of the Association of Official Analytical Chemistry. 16th. Washington, USA: AOAC International. 1141.

Badawi, H. K. 1971. On the chemical composition of the red crab, Portuns pelagicus. Mar. Biol. 11: $198-200$. doi:10.1007/BF00401267.

Balasubramanian, C. P., and Suseelan, C. 2001a. Distribution and population structure of deep water crab Charybdis smithii (Decapoda: Portunidae) in the Arabian Sea and Bay of Bengal. Bull. Mare Sci. 68(3): 435-449.

Balasubramanian, C. P., and Suseelan, C. 2001b. Biochemical composition of the deep-water crab Charybdis smithii. Indian J. Fish. 48(3): 333-335.

Chakraborty, K., Joy, M., and Vijayagopal, P. 2016. Nutritional qualities of common edible cephalopods at the Arabian Sea. Int. Food Res. J. 23(5): 1926-1938.

Chigozie, O., and Kolade, O. 2015. Microbial and proximate composition of blue crab callinectes sapidus from agbalata market badagry Lagos West, Nigeria. Am J Agric Sci. 2( 2): 13-17.

Dey Snigdha, K., Misra, K., and Homechoudhuri, S. 2017. Reviewing nutritional quality of small freshwater fish species. Am. J. Food Nutr. 5(1): 19-27.

Dineshbabu, A. P. 2011. Biology and exploitation of the crucifix crab, Charybdis (Charybdis) feriata (Linnaeus, 1758) (Brachyura: Portunidae) from Karnataka coast, India. Indian J. Fish. 58(1): 25-29.

Dineshbabu, A. P., Thomas, S., and Radhakrishnan, E. V. 2012. Spatio-temporal analysis and impact assessment of trawl bycatch of Karnataka to suggest operation based fishery management options. Indian J. Fish. 59(2): 27-38.

Hofmann, D., Gehre, M., and Jung, K. 2003. Sample preparation techniques for the determination of natural ${ }^{15} \mathrm{~N} /{ }^{14} \mathrm{~N}$ variations in amino acids by gas chromatography-combustion-isotope ratio mass spectrometry (GC-C-IRMS). Isotopes Environ. Health Studies. 39: 233-244. doi:10.1080/1025601031000147630. 
Hofmann, D., Jung, K., Bender, J., Gehre, M., and Schüürmann, G. 1997. Using natural isotope variations of nitrogen in plants an early indicator of air pollution stress. J. Mass Spectrom. 32: 855-863. doi:10.1002/(SICI)1096-9888(199708)32:8<855::AID-JMS544>3.0.CO;2-J.

Horwitz, W., W Latimer, G. 2005. Official methods of analysis of the association of official analytical chemists (18th ed.). Gaithersburg, MD: AOAC International.

Humphries, E. C. 1956. Mineral composition and ash analysis. In: Modern Methods of Plant Analysis. Peach, K., and Tracey, M. V., (Eds.). Vol. 1. Berlin: Springer. Pp. 468-502.

Jandacek, J. R. 2017. Linoleic acid: A nutritional quandary. Healthcare. 5(2): 25. doi:10.3390/healthcare5020025.

Jeyalakshmi, K. L., and Chandran, M. 2014. Chemical composition of brachyuran crabs from various environments. Int. J Pharm. Bio. Sci. 5(4): 612-620.

Kathirvel, K., Eswar, A., Manikandarajan, T., Ramamoorthy, K., Sankar, G., and Anbarasu, R. 2014. Proximate composition, amino acid, fatty acid and mineral analysis of box crab, Calappa lophus (Herbst, 1782) from parangipettai, southeast coast of India. IOSR J. Environ. Sci. Toxicol. Food Technol. 8(5): 50-57. doi:10.9790/ 2402-08525057.

Kelleher, K. 2005.Discards in the world's marine fisheries. An update. FAO Fisheries Technical Paper. No. 470. Rome, FAO.131.

Kris-Etherton, P. M., Harris, W. S., and Appel, L. J. 2002. Fish consumption, fish oil, omega -3 fatty acid and cardiovascular disease. Circulation 106: 2747-2757.

Latimer, G. W. 2012. Official Methods of Analysis of AOAC International. (19th.). Vol. Chapter 2. Gaithersburg, MD, USA: AOAC International. 42. 2.6.35.

Musaiger, A. O., and Al-Rumaidh, M. J. 2005. Proximate and mineral composition of crab meat consumed in Bahrain. Int. J. Food Sci. Nutr. 56(4): 231-235. doi:10.1080/09637480500146945.

Nareshkumar, S. 2007. Capillary gas chromatography method for fatty acid analysis of coconut oil. J. Plant. Crops. 35 : 23-27.

Nelson, D. L. A. W. H., and Cox, M. C. 2004. Lehninger: Principles of Biochemistry. 4th. New York: Freeman \& Co. 670.

Oramadike, C., and Oluwakemi, K. 2015. Microbial and proximate composition of blue crab callinectes sapidus from agbalata market badagry lagos West, Nigeria. A J A S. 2(2): 13-17.

Padua-Resurreccion, A. B., and Banzon, J. A. 1979. Fatty acid composition of the oil from progressively maturing bunches of coconut. PJCS. 4: 1-15.

Premarathna, A. D., Kumara., A. M. C. P., Jayasooriya., A. P., Satharasinghe, D. A., and Pathirana, E. 2018. Proximate analyses of Nile tilapia (Oreochromis niloticus) and Black tiger prawn (Penaeus monodon) from Sri Lanka. Oceanogr. Fish. Open Access J. 7(5): 01-05.

Premarathna, A. D., Rajapakse, R. P. V. J., Pathirana, E., Senaratne, V. P., Karunarathna, S. C., and Jayasooriya, A. P. 2015. Nutritional analysis of some selected fish and crab meats and fatty acid analysis of oil extracted from Portunus pelagicus. IJSTR. 4(07): 192-201.

Radhakrishnan, C. K., and Natarajan, R. 1979. Nutritive value of the crab Podophthalmus vigil (Fabricius). Fish. Technol.. 16: 37-38.

Radhakrishnan, E. V., Manisseri, K. M., and Nandakumar, G. 2007. Status of research on crustacean resources. In: Status and Perspectives in Marine Fisheries Research in India. Cochin: Central Marine Fisheries Research Institute. Pp. 135-172.

Romanov, E. V., Potier, M., Zamorov, B., and Ménard, F. 2009. The swimming crab Charybdis smithii: distribution, biology and trophic role in the pelagic ecosystem of the western indian . Ocean. Mar. Biol. 156: 1089. doi:10.1007/s00227-009-1151-Z

Rosli, W. W., Rohana, A. J., Gan, S. H., Fadzlina, H. N., Rosliza, H., Helmy, H., ... \& Imran, M. K. 2012. Fat content and EPA and DHA levels of selected marine, freshwater fish and shellfish species from the east coast of peninsular Malaysia. IFRJ. 19(3): 815-821.

Silas, E. G. 1969. Exploratory fishing by R. V. Varuna. Bull. Central Mar. Fish. Res. Inst. 12: 1-86.

Soundarapandian, P., Varadharajan, D., and Ravichandran, S. 2014. Mineral composition of edible crab Podophthalmus vigil Fabricius (Crustacea: Decapoda). Arthropods. 3(1): 20-26.

Soundarapandian, P., Varadharajan, D., and Sivasubramanian, C. 2013. Mineral composition of edible crab, Charybdis natator herbst (Crustacea: Decapoda). J. Bioanal. Biomed. 5(4): 99-101.

SPSS Inc. 2007. SPSS for Windows, Version 16.0. Chicago: SPSS Inc.

Sulochanan, P. K., Nair, N. V., and Sudarsan, D. 1991. Deep sea crustacean resources of the Indian exclusive economic zone. Proceedings of National Workshop on Fisheries Resources Data and Fishing Industry. Fisheries Survey of India, Cochin, India. Pp. 98-107.

Swanson, D., Robert, B., and Mousa Shaker, A. 2012. Omega-3 fatty acids epa and dha: Health benefits throughout life. American Soc.Nutrition. Adv. Nutr. 3: 1-7. doi:10.3945/an.111.000893.

Thomas, M. 1985. Studies on Portunid Crabs, Ph.D. Thesis, Cochin. Kerala, India: Cochin Univ. Sci. Technol. 155.

Vijayagopal, P., Chakraborty, K., Iyyapparajanarasimapallavan, G., Vijayan, K. K., and Tissera, K. 2015. Evaluation of formulated diets with different levels of marine protein mixtures in aquariculture of koi carp cyprinus carpio var. koi (linnaeus, 1758). Indian J. Fish. 62(3): 89-99.

Worm, B., Barbier, E. B., Beaumont, N., et al. 2006. Impacts of biodiversity loss on ocean ecosystem services. Science. 314: 787-790. doi:10.1126/science.1132294. 